\title{
Potential alternative feed sources for ruminant feeding from the biodiesel production chain by-products
}

\author{
C.S. Pinto ${ }^{1}$, A.L.R. Magalhães ${ }^{1}$, A.L. Teodoro ${ }^{2}$, G.C. Gois ${ }^{3 \#}$, R.M. L. Véras ${ }^{1}$, F.S. Campos ${ }^{1}$, \\ D.B. Nascimento ${ }^{1}$, A.P. Andrade ${ }^{1}$, L.P. Oliveira $^{4} \&$ I.E. Lima ${ }^{1}$ \\ ${ }^{1}$ Academic Unit of Garanhuns, Federal Rural University of Pernambuco, Garanhuns-PE, Brazil. \\ ${ }^{2}$ Federal Institute of Education, Science and Technology of Piauí, Corrente - PI, Brazil \\ ${ }^{3}$ Postgraduate Program in Veterinary Sciences in the Semiarid, Federal University of San Francisco Valley, Petrolina - \\ PE, Brazil. \\ ${ }^{4}$ Integrated PhD Program in Animal Science, Federal University of Paraíba, Areia-PB, Brazil
}

(Received 25 March 2019; Accepted 5 January 2020; First published online 16 February 2020)

\author{
Copyright resides with the authors in terms of the Creative Commons Attribution 4.0 South African License. \\ See: http://creativecommons.org/licenses/by/4.0/za \\ Condition of use: The user may copy, distribute, transmit and adapt the work, but must recognize the authors and the South African \\ Journal of Animal Science.
}

\begin{abstract}
This study aimed to evaluate the chemical composition, fractionation of nitrogen compounds and carbohydrates, digestibility parameters, gas production kinetics and ruminal fermentation of fruit seed cakes. The experiment was conducted in a completely randomized design with three fruit seed cakes (treatments) and four replications. The cakes were made of seeds of custard apple (Annona squamosa), soursop (Annona muricata) and passion fruit (Passiflora edulis), which were collected in a biodiesel plant. The passion fruit seed cake presented the highest content of dry matter, neutral detergent fibre crude protein (NDFcp), acid detergent fibre (ADF), lignin and total carbohydrates $(P<0.05)$. The custard apple seed cake presented high proportions of crude protein, condensed tannins and digestible energy $(P<0.05)$. The soursop seed cake presented higher values for ether extract and total digestible nutrients $(P<0.05)$. For potential degradability, the authors detected a difference between the custard apple, soursop and passion fruit seed cakes. The total volume of gases was higher for custard apple and soursop seed cakes. Custard apple seed cake presented higher proportions of in vitro degradation parameters $(P<0.05)$. Thus this cake could provide greater nutrient levels when supplied in ruminant diets, followed by soursop seed cake and passion fruit seed cake.
\end{abstract}

Keywords: alternative food, by-products, ruminant feeding, seed cake, semi-arid

\#Corresponding Author: glayciane_gois@yahoo.com.br

\section{Introduction}

In arid and semi-arid regions, shortages of forage are observed every year and these periods of scarcity negatively affect productivity of ruminant livestock. Because of this, it is recommended to supplement animals during periods of shortage with conserved forage and concentrates to correct nutritional deficiencies, which increases production costs and reduces profitability (Maneerat et al., 2015). Thus, the use of cost-effective alternative food sources may be a strategy that has a great impact on the viability of livestock (Tinsley et al., 2019).

The growing interest in the use of agro-industrial by-products as animal feed is because of increased environmental and economic concerns (Almeida et al., 2019). A large volume of agro-industrial waste is produced annually in Brazil from crop processing to food and fibre production. Some by-products are restricted to certain regions, while others are found throughout the country. Successful use of these byproducts in animal feed is often limited by poor knowledge of their nutritional characteristics and economic value as feed ingredients, as well as the lack of performance data of animals fed this type of feed (TorresLéon et al., 2018).

The use of by-products that are generated in the biodiesel production chain directly influences the economic and environmental viability of replacing diesel with biodiesel (Lima et al., 2018). The main byproducts are obtained after oil extraction from oilseeds (cake and meal) and converting triglycerides into 
biodiesel by transesterification (crude glycerin), which account for more than $50 \%$ initial seed mass used in the agro-industrial chain (Goes et al., 2019).

Cakes from biodiesel production such as palm kernel (Keles et al., 2017), babassu (Luz et al., 2019), castor bean (Nagalakshmi \& Dhanalakshmi, 2015), sunflower (Lima et al., 2018), cottonseed cake (Assis et al., 2019), and other by-products (Olivo et al., 2017) present considerable concentrations of protein and ether extract, which characterize them as protein and energy foods (Goes et al., 2019) that meet the nutritional requirements of animals and allow their use in ruminant feeding. However, the implications of using these cakes, whether positive or negative, are still poorly understood.

The nutritional compositions of custard apple (Annona squamosa), soursop (Annona muricata) and passion fruit (Passiflora edulis) seed cakes from oil extraction in biodiesel plants have not yet been studied. Therefore, the aim of this study was to evaluate the chemical composition, the fractionation of carbohydrates and nitrogen compounds, digestibility parameters, gas production kinetics and ruminal fermentation of these fruit seed cakes.

\section{Material and Methods}

The study was conducted at the Federal Rural University of Pernambuco/Garanhuns Academic Unit (UFRPE/UAG), Garanhuns, State of Pernambuco, Brazil. Samples were collected at the Experimental Biofuel Plant of the Centre for Strategic Technologies of the Northeast (CETENE), in Caetés, State of Pernambuco, Brazil. Their study follows the principles of the Declaration of Helsinki. The experiment was conducted in a completely randomized design with three fruit seed cakes (treatments) and four replications. The cakes were custard apple (Annona squamosa), soursop (Annona muricata) and passion fruit (Passiflora edulis) seed cake.

Samples were pre-dried in a forced ventilation oven at $55{ }^{\circ} \mathrm{C}$ for 72 hours and ground in a Wiley mill (Marconi, MA-580, Piracicaba, Brazil) with 2-mm and 1-mm sieves. Analyses for dry matter (DM) (method 967.03), mineral matter (MM) (method 942.05), crude protein (CP) (method 981.10) and ether extract (EE) (method 920.29) were performed according to the methodologies described by the Association of Official Analytical Chemists (AOAC 2016). Neutral detergent fibre (NDF) and acid detergent fibre (ADF) were determined according to Van Soest et al. (1991). Neutral detergent fibre corrected for ash (a) and protein (p) (NDFap) was determined according to Mertens (2002) and Licitra et al. (1996). Lignin (LIG) was determined by treating ADF residue with $72 \%$ sulfuric acid (Silva \& Queiroz, 2002). The hemicellulose (HEM) and cellulose (CEL) fractions were estimated by the equations: HEM = NDFap - ADF; and CEL = ADF - LIG, respectively (Silva \& Queiroz, 2002). Total digestible nutrient (TDN) and digestible energy (DE) values were estimated using equations proposed by the National Research Council (NRC 2001). Tannin was analysed by butanol-HCl methodology proposed by Terrill et al. (1992).

Total carbohydrates (TC) were quantified according to Sniffen et al. (1992), in which

$$
\mathrm{TC}(\mathrm{DM})=100-(\mathrm{CP}+\mathrm{EE}+\mathrm{MM}) .
$$

Non-fibre carbohydrates (NFC), corresponding to fractions $A+B 1$, were obtained from the difference between TC and NDFcp. Fraction C was obtained by indigestible NDF after 288 hours of in situ incubation (Valente et al., 2011). Fraction B2, which corresponds to the available fibre fraction, was obtained from the difference between NDFcp and fraction C (indigestible fibre).

Protein fractionation was calculated by the CNCPS system (Sniffen et al., 1992). Protein was analysed and calculated for the five fractions of $A, B 1, B 2, B 3$, and C. Fraction A was determined by the difference between total nitrogen and trichloroacetic acid insoluble $\mathrm{N}$ (TCA) with the formula

$$
\mathrm{A}(\% \mathrm{Nt})=\mathrm{Nt}-\mathrm{N} 1 / \mathrm{Nt} \times 100,
$$

Where: $\mathrm{Nt}=$ total nitrogen in the sample and

$\mathrm{N} 1$ = trichloroacetic acid insoluble nitrogen content.

Fraction $\mathrm{B} 1$ refers to the soluble protein, rapidly degraded in the rumen, which is obtained from the difference between borate phosphate buffer (TBF) insoluble nitrogen minus NPN from the formula:

$$
\mathrm{B} 1(\% \mathrm{Nt})=\mathrm{N} 1-\mathrm{N} 2 / \mathrm{Nt} \times 100,
$$

Where: $\mathrm{N} 2$ = borate phosphate buffer insoluble nitrogen. 
Fractions B2 and B3 consisted of insoluble protein with slow intermediate rumen degradation rate, determined by the difference between borate phosphate buffer insoluble nitrogen and NDIN, and NDIN minus ADIN, respectively. B2 is obtained from B2 $(\% \mathrm{Nt})=\mathrm{N} 2-\mathrm{NDIN} / \mathrm{Nt} \times 100$ and fraction $\mathrm{B} 3$, with B3 $(\% \mathrm{Nt})=\mathrm{NDIN}-\mathrm{ADIN} / \mathrm{Nt} \times 100$. Fraction $\mathrm{C}$, formed by insoluble protein that is indigestible in the rumen and intestine, was determined by the residual nitrogen content of the sample after treatment with acid detergent and expressed as a percentage of $\mathrm{Nt}$ of the sample.

In vitro dry matter degradability (IVDMD) was performed according to the first stage of the methodology of Tilley and Terry (1963) using nutrient medium by in vitro incubation of $600 \mathrm{mg}$ air-dried sample with $60 \mathrm{~mL}$ buffer solution (combination of $A+B$ solutions with $\mathrm{pH}$ 6.8) and $15 \mathrm{~mL}$ rumen inoculum collected from two rumen-fistulated sheep, filtered through four layers of gauze, and constantly injecting carbon dioxide to maintain the anaerobic environment.

Samples were incubated for $0,3,6,9,12,18,24,36$, and 48 hours. At time zero, samples were subjected to washing with distilled water at $39^{\circ} \mathrm{C}$ only. For the other times, the samples were incubated in a greenhouse with a constant temperature of $39^{\circ} \mathrm{C}$.

In vitro degradation parameters $(a, b$, and $c)$ and dry matter degradability potential were estimated using the model proposed by Ørskov and McDonald (1979), with the aid of nonlinear procedure (PROC NLIN) of SAS software (version 9.2, SAS Institute Inc., Cary, North Carolina, USA), namely

$$
D P=a+b\left(1-e^{-c t}\right)
$$

Where: DP is the actual percentage of nutrients degraded after $t$ hours of incubation, $a$ is the readily soluble fraction,

$b$ is the fraction that can be degraded if time permits,

$c$ is the degradation rate or speed of fraction $b$, and

$t$ is the incubation time.

To estimate the effective degradability (ED), the following equation was used:

$$
\mathrm{ED}=a+\left(b^{*} c\right) /(c+\mathrm{k})
$$

Where: $\mathrm{k}$ is the rate of passage of food. Rates of passage of ruminal particles are estimated at $0.02,0.05$, and $0.08 \% / h$, as suggested by AFRC (1993).

Analysis for in vitro dry matter digestibility (IVDMD) was conducted according to Tilley and Terry (1963), with modifications proposed by Holden (1999), with in vitro incubations of $1 \mathrm{~g}$ air-dried sample with $80 \mathrm{~mL}$ buffer solution and $20 \mathrm{~mL}$ ruminal fluid, filtered through four layers of gauze, constantly injecting carbon dioxide to maintain the anaerobic environment. After 48 hours of incubation, $6 \mathrm{~mL} 20 \%$ hydrochloric acid $(\mathrm{HCl})$ and $2 \mathrm{~mL}$ pepsin (1: 1000) were added to each vial. After 24 hours of incubation, vacuum-filtered residues were dried and weighed to calculate the IVDMD.

Gas production kinetics was analysed with the in vitro technique using the pressure transducer proposed by Theodorou et al. (1994). One gram of the sample was placed in glass vials $(160 \mathrm{~mL})$, to which $90 \mathrm{~mL}$ nutrient medium was added (Theodorou et al., 1994). Subsequently, $10 \mathrm{~mL}$ rumen fluid from the rumen of three sheep was added to each vial, which was kept under $\mathrm{CO}_{2}$ aspersion. These were sealed with rubber stoppers and aluminium seals. Cumulative gas production was quantified with a pressure transducer (Datalogger Universal Logger AG100 - Agricer). The readings were taken at a higher rate in the initial period and at a lower rate at the end of the study period $(2,4,6,8,10,12,15,18,21,24,30,36,42$, and 48 hours of incubation). The data obtained in PSI (pressure per square inch) were transformed to $\mathrm{mL}$ to obtain the volume of gases $(\mathrm{V})$ produced during incubation, using the equation:

$$
Y=5.1612 \text { * psi }-0.3017, R^{2}=0.9873
$$

which was developed at the Gas Production Laboratory of the Garanhuns Academic Unit, UFRPE, based on 937 observations, in which $1 \mathrm{psi}=4.859 \mathrm{~mL}$ of gas. The total produced by the bottles without substrate (white) for each sample was subtracted from each pressure reading

Data from chemical analysis, fractionation of carbohydrates and nitrogen compounds and IVDMD were tested by analysis of variance using the PROC GLM procedure. Cumulative gas production data were adjusted by the two-compartment model suggested by Schofield et al. (1994) using the NLMIXED procedure of SAS (version 9.2, SAS Institute Inc., Cary, North Carolina, USA): 


$$
\mathrm{V}_{\mathrm{t}}=\left(\mathrm{V} f 1 / 1+\mathrm{e}^{[2-4 k d 1(\mathrm{t}-\lambda)]}\right)+\left(\mathrm{V} f 2 / 1+\mathrm{e}^{[2-4 k d 2(\mathrm{t}-\lambda)]}\right)
$$

Where: $\mathrm{Vt}=$ total volume of gases produced

$\mathrm{V}_{\mathrm{fl}}=$ volume of gases produced by the degradation of fraction $\mathrm{A}+\mathrm{B} 1$ (NFC) of the CNCPS system with rapid fermentation

$\mathrm{V}_{\mathrm{f} 2}=$ volume of gases produced by degradation of fraction B2 (FC) of the CNCPS system with slow degradation

$\mathrm{k}_{1}=$ specific gas production rate by degradation of fraction $\mathrm{A}+\mathrm{B} 1$ (NFC)

$\mathrm{k}_{2}=$ specific gas production rate by degradation of fraction $\mathrm{B} 2$ (FC)

$\mathrm{t}=$ fermentation time

$\lambda=\operatorname{lag}$ time

Mean values were compared with Tukey's test at $5 \%$ significance, using the statistical software SAS (version 9.2, SAS Institute Inc., Cary, North Carolina, USA).

\section{Results}

The cakes showed differences in chemical composition $(P<0.05)$. The passion fruit seed cake presented the highest dry matter content $(912.8 \mathrm{~g} / \mathrm{kg} \mathrm{DM})$, NDFap $(677.1 \mathrm{~g} / \mathrm{kg} \mathrm{DM})$, ADF $(653.0 \mathrm{~g} / \mathrm{kg} \mathrm{DM})$, lignin $(426.0 \mathrm{~g} / \mathrm{kg} \mathrm{DM})$ and total carbohydrates $(750.7 \mathrm{~g} / \mathrm{kg}$ DM) (Table 1). The custard apple seed cake contained high proportions of crude protein $(216.7 \mathrm{~g} / \mathrm{kg} \mathrm{DM})$, condensed tannins $(65.5 \mathrm{~g} / \mathrm{kg} \mathrm{DM})$ and digestible energy (15.06 MJ/kg DM). Soursop seed cake contained higher values for ether extract (194.6 $\mathrm{g} / \mathrm{kg} \mathrm{DM}$ ) and total digestible nutrients (789.1 g/kg DM) (Table 1). The highest contents of NDIP, ADIP, hemicellulose and cellulose were found for custard apple and soursop seed cakes $(P<0.05)$ (Table 1$)$.

Table 1 Chemical composition of custard apple seed cake, soursop seed cake and passion fruit seed cake used in oil extraction for biodiesel production

\begin{tabular}{|c|c|c|c|c|c|}
\hline \multirow{2}{*}{ Variables } & \multicolumn{3}{|c|}{ Seeds cake } & \multirow{2}{*}{ SEM } & \multirow{2}{*}{$P$ Value } \\
\hline & Custard apple & Soursop & Passion fruit & & \\
\hline Dry matter $^{1}$ & $874.9^{b}$ & $852.5^{\mathrm{b}}$ & $912.8^{\mathrm{a}}$ & 8.2 & 0.0003 \\
\hline Mineral matter ${ }^{2}$ & $22.1^{\mathrm{a}}$ & $17.3^{\mathrm{b}}$ & $16.7^{b}$ & 0.8 & 0.0002 \\
\hline Organic matter $^{2}$ & $977.9^{b}$ & $982.7^{\mathrm{a}}$ & $983.3^{\mathrm{a}}$ & 0.8 & 0.0002 \\
\hline Ether extract ${ }^{2}$ & $165.1^{b}$ & $194.6^{\mathrm{a}}$ & $59.4^{\mathrm{C}}$ & 17.9 & $<0.0001$ \\
\hline Crude protein ${ }^{2}$ & $216.7^{\mathrm{a}}$ & $164.1^{b}$ & $173.2^{b}$ & 7.1 & $<0.0001$ \\
\hline Condensed tannins $^{2}$ & $65.5^{\mathrm{a}}$ & $35.0^{\mathrm{b}}$ & $34.5^{\mathrm{b}}$ & 4.6 & $<0.0001$ \\
\hline Neutral detergent insoluble protein ${ }^{3}$ & $479.0^{\mathrm{a}}$ & $472.0^{\mathrm{a}}$ & $206.3^{b}$ & 39.0 & $<0.0001$ \\
\hline Acid detergent insoluble protein ${ }^{3}$ & $324.4^{\mathrm{a}}$ & $323.2^{\mathrm{a}}$ & $87.0^{\mathrm{b}}$ & 33.8 & $<0.0001$ \\
\hline NDFap $^{2}$ & $515.8^{c}$ & $561.5^{\mathrm{b}}$ & $677.1^{\mathrm{a}}$ & 20.6 & $<0.0001$ \\
\hline Acid detergent fibre $^{2}$ & $371.1^{\mathrm{c}}$ & $410.6^{b}$ & $653.0^{\mathrm{a}}$ & 37.6 & $<0.0001$ \\
\hline Hemicellulose $^{2}$ & $144.7^{\mathrm{a}}$ & $150.9^{\mathrm{a}}$ & $24.1^{b}$ & 17.8 & $<0.0001$ \\
\hline Acid detergent lignin ${ }^{2}$ & $94.5^{\mathrm{c}}$ & $127.2^{b}$ & $426.0^{\mathrm{a}}$ & 45.0 & $<0.0001$ \\
\hline Cellulose $^{2}$ & $276.7^{\mathrm{a}}$ & $283.4^{\mathrm{a}}$ & $227.0^{\mathrm{b}}$ & 7.9 & $<0.0001$ \\
\hline Non-fibre carbohydrates $^{2}$ & 79.0 & 62.3 & 73.6 & 4.1 & 0.2470 \\
\hline Total carbohydrates $^{2}$ & $594.8^{c}$ & $623.8^{b}$ & $750.7^{\mathrm{a}}$ & 20.6 & $<0.0001$ \\
\hline Total digestible nutrients ${ }^{2}$ & $804.5^{\mathrm{a}}$ & $789.1^{\mathrm{a}}$ & $358.5^{b}$ & 62.5 & $<0.0001$ \\
\hline Digestible energy ${ }^{4}$ & $15.06^{\mathrm{a}}$ & $14.64^{b}$ & $7.11^{\mathrm{c}}$ & 0.3 & $<0.0001$ \\
\hline
\end{tabular}

${ }^{1} \mathrm{~g} / \mathrm{kg}$ of natural material; ${ }^{2} \mathrm{~g} / \mathrm{kg}$ of dry matter; ${ }^{3} \mathrm{~g} / \mathrm{kg}$ of crude protein; ${ }^{4} \mathrm{MJ} / \mathrm{kg}$ of dry matter; NDFap: neutral detergent fibre corrected for ash and protein; SEM: standard error of mean; means followed by the same letter do not differ $(P>0.05)$ by Tukey test 
For nitrogen compounds, the highest proportions of fractions $\mathrm{B} 1+\mathrm{B} 2$ (high and intermediate ruminal degradation) were observed in passion fruit seed cake $(656.3 \mathrm{~g} / \mathrm{kg} \mathrm{CP})(P<0.05)$. Custard apple $(324.4 \mathrm{~g} / \mathrm{kg}$ $\mathrm{CP}$ ) and soursop (323.3 $\mathrm{g} / \mathrm{kg} \mathrm{CP}$ ) seed cakes presented the highest content of unavailable nitrogen fraction (fraction C) (Table 2). Fractions A and B3 were similar between the cakes $(P>0.05)$ (Table 2).

For carbohydrate fractionation, soursop seed cake showed the highest proportion of fraction B2 (253.0 $\mathrm{g} / \mathrm{kg} \mathrm{TC}$ ). passion fruit seed cake presented the highest concentration of fraction $\mathrm{C}(860.7 \mathrm{~g} / \mathrm{kg} \mathrm{TC})$, which is composed of non-digestible fibres $(P<0.05)$ (Table 2). No differences were detected for fraction $\mathrm{A}+\mathrm{B} 1$ between the seed cakes $(P>0.05)$ (Table 2).

Table 2 Nitrogen compound and total carbohydrate fractions of custard apple seed cake, soursop seed cake and passion fruit seed cake used in oil extraction for biodiesel production

\begin{tabular}{|c|c|c|c|c|c|}
\hline \multirow{2}{*}{ Variables } & \multicolumn{3}{|c|}{ Seeds cake } & \multirow{2}{*}{ SEM } & \multirow{2}{*}{$P$ Value } \\
\hline & Custard apple & Soursop & Passion fruit & & \\
\hline \multicolumn{6}{|c|}{ Fractions of nitrogen compounds } \\
\hline Crude protein ${ }^{1}$ & $216.7^{\mathrm{a}}$ & $164.1^{\mathrm{b}}$ & $173.2^{b}$ & 7.1 & $<0.0001$ \\
\hline$A^{2}$ & 179.8 & 130.9 & 137.4 & 12.2 & 0.22 \\
\hline $\mathrm{B} 1+\mathrm{B} 2^{2}$ & $341.2^{b}$ & $397.0^{b}$ & $656.3^{\mathrm{a}}$ & 42.4 & $<0.0001$ \\
\hline $\mathrm{B}^{2}$ & 154.7 & 148.8 & 119.3 & 8.3 & 0.18 \\
\hline$C^{2}$ & $324.4^{\mathrm{a}}$ & $323.3^{\mathrm{a}}$ & $87.0^{\mathrm{b}}$ & 33.8 & $<0.0001$ \\
\hline \multicolumn{6}{|c|}{ Fractions of carbohydrate compounds } \\
\hline Total carbohydrates ${ }^{1}$ & $594.8^{\mathrm{C}}$ & $623.8^{\mathrm{b}}$ & $750.7^{\mathrm{a}}$ & 20.6 & $<0.0001$ \\
\hline $\mathrm{A}+\mathrm{B} 1^{3}$ & 132.7 & 99.4 & 98.1 & 7.2 & 0.07 \\
\hline $\mathrm{B}^{3}{ }^{3}$ & $160.1^{\mathrm{b}}$ & $253.0^{\mathrm{a}}$ & $41.3^{c}$ & 28.1 & 0.0001 \\
\hline$C^{3}$ & $707.2^{b}$ & $647.6^{\mathrm{b}}$ & $860.7^{\mathrm{a}}$ & 28.2 & $<0.0001$ \\
\hline
\end{tabular}

T $\mathrm{g} / \mathrm{kg}$ of dry matter; ${ }^{2} \mathrm{~g} / \mathrm{kg}$ of crude protein; ${ }^{3} \mathrm{~g} / \mathrm{kg}$ of total carbohydrates; SEM: standard error of mean; means followed by the same letter do not differ $(P>0.05)$ by Tukey test

Custard apple seed cake had higher levels of in vitro ruminal degradability parameters $(P<0.05)$ (Table 3). In gas production kinetics, the highest cumulative total was found for the custard apple seed cake $\left(\mathrm{Vt}_{1}=133.3 \mathrm{~mL} / \mathrm{g}\right.$ incubated DM) (Table 3). Gas production from non-fibre carbohydrate (Vf1) fermentation was similar between the custard apple and soursop seed cakes, with volumes of 98.7 and $102.1 \mathrm{~mL} / \mathrm{g}$ incubated DM, respectively. For gas production from fibre carbohydrates (Vf2), the highest cumulative volume was found for custard apple seed cake (Table 3).

\section{Discussion}

Seed cakes of custard apple, soursop and passion fruit had a low moisture content, and consequently had a high dry matter content (Table 1), which allows better and longer storage for use in animal feed. This low moisture content is the result of the industrial processes in which the seeds are subjected to oil extraction for biodiesel production.

The cakes had higher lipid concentrations than are recommended for ruminant diets, which, according to the NRC (2001), should not exceed 5\% EE. The high lipid content in ruminant diets impairs nutrient digestibility and feed intake. Therefore, the inclusion of these by-products in the ruminant diet should be done so as not to exceed the dietary levels of $E E$, ensuring the maintenance of a healthy rumen environment.

Custard apple seed cake has a significant higher of crude protein content (Table 1). These values are relatively high and classify this cake as a potential protein food (>20\% CP) in animal diets. Neutral (NDIP) and acid (ADIP) detergent fibre insoluble protein values may increase with the presence of tannins and lignin in their composition and affect protein degradability (Braga et al., 2016). The presence of tannins in seed cakes is considered high in relation to conventional foods that are part of the ruminant diet. Custard apple seed cake contained approximately $47 \%$ more tannin than the others. However, this cake had the highest 
proportions of digestible compounds from in vitro techniques. The non-interference of these secondary compounds with digestion can be explained by the ruminal bioactivity of the tannins present.

Table 3 Kinetics of degradation and in vitro gas production of custard apple seed cake, soursop seed cake and passion fruit seed cake used in oil extraction for biodiesel production

\begin{tabular}{|c|c|c|c|c|c|}
\hline \multirow{2}{*}{ Variables } & \multicolumn{3}{|c|}{ Seeds cake } & \multirow{2}{*}{ SEM } & \multirow{2}{*}{$P$ Value } \\
\hline & Custard apple & Soursop & Passion fruit & & \\
\hline \multicolumn{6}{|c|}{ Degradation kinetics } \\
\hline$a^{1}$ & $45.3^{\mathrm{a}}$ & $38.6^{\mathrm{a}}$ & $11.9^{\mathrm{b}}$ & 5.5 & 0.01 \\
\hline$b^{1}$ & $484.5^{\mathrm{a}}$ & $346.5^{\mathrm{b}}$ & $227.7^{\mathrm{C}}$ & 33.6 & $<0.0001$ \\
\hline$c_{(\% \%)}$ & $0.05^{\mathrm{a}}$ & $0.03^{\mathrm{b}}$ & $0.04^{\mathrm{ab}}$ & 0.003 & 0.01 \\
\hline $\mathrm{ED}_{(0.02 / \mathrm{h})}{ }^{1}$ & $385.3^{a}$ & $235.4^{\mathrm{b}}$ & $162.2^{c}$ & 28.3 & $<0.0001$ \\
\hline $\mathrm{ED}_{\left(0.05 / \mathrm{h}^{1}\right.}$ & $280.5^{\mathrm{a}}$ & $158.6^{b}$ & $111.9^{c}$ & 21.8 & $<0.0001$ \\
\hline $\operatorname{ED}_{(0.08 / h)}{ }^{1}$ & $225.2^{\mathrm{a}}$ & $125.0^{b}$ & $86.9^{c}$ & 18.0 & $<0.0001$ \\
\hline $\mathrm{PD}^{1}$ & $529.8^{\mathrm{a}}$ & $385.2^{b}$ & $239.6^{c}$ & 37.3 & $<0.0001$ \\
\hline $\mathrm{ED}_{48 \mathrm{~h}}{ }^{1}$ & $464.4^{\mathrm{a}}$ & $275.4^{b}$ & $201.6^{c}$ & 33.5 & $<0.0001$ \\
\hline IVDMD $^{1}$ & $517.7^{\mathrm{a}}$ & $437.3^{\mathrm{b}}$ & $271.9^{c}$ & 31.3 & $<0.0001$ \\
\hline \multicolumn{6}{|c|}{ Gas production kinetics } \\
\hline $\mathrm{Vt}_{1}{ }^{2}$ & $133.3^{\mathrm{a}}$ & $111.9^{\mathrm{b}}$ & $46.1^{\mathrm{C}}$ & 11.3 & $<0.0001$ \\
\hline $\mathrm{Vt}_{2}{ }^{2}$ & $133.7^{\mathrm{a}}$ & $119.0^{\mathrm{a}}$ & $47.4^{\mathrm{b}}$ & 11.6 & $<0.0001$ \\
\hline$V f_{1}{ }^{2}$ & $98.7^{\mathrm{a}}$ & $102.1^{\mathrm{a}}$ & $29.3^{b}$ & 10.3 & $<0.0001$ \\
\hline $\mathrm{k}_{1 \text { (h) }}$ & 0.03 & 0.03 & 0.03 & 0.001 & 0.27 \\
\hline$\lambda_{(\mathrm{h})}$ & $7.5^{\mathrm{b}}$ & $9.3^{\mathrm{a}}$ & $7.8^{\mathrm{b}}$ & 0.3 & 0.002 \\
\hline $\mathrm{V}_{2}{ }^{2}$ & $35.0^{\mathrm{a}}$ & $16.9^{b}$ & $18.0^{\mathrm{b}}$ & 3.0 & 0.005 \\
\hline $\mathrm{k}_{2(\mathrm{~h})}$ & $0.12^{\mathrm{C}}$ & $0.24 a$ & $0.20^{\mathrm{b}}$ & 0.02 & $<0.0001$ \\
\hline
\end{tabular}

$\mathrm{g} / \mathrm{kg}$ of dry matter; ${ }^{2} \mathrm{~mL} / \mathrm{g}$ dry matter incubated; $a, b$ and $c$ refer to parameters of Ørskov \& McDonald (1979); ED: effective degradability for a passage rate of $0.02,0.05$ and $0.08 \mathrm{~h}^{-1}$; Pd: potential degradability represented by the sum of $a$ and $b$; ED 48 : effective degradability observed within 48 hours after incubation; IVDMD: in vitro true dry matter digestibility. $\mathrm{Vt}_{1}$ : total volume observed $(\mathrm{mL} / \mathrm{g} \mathrm{DM}) ; \mathrm{Vt}_{2}$ : total volume of gas adjusted by model $(\mathrm{mL} / \mathrm{gDM}) ; \mathrm{V}_{1}$ : volume $(\mathrm{mL})$ of gas produced by the degradation of the fraction $A+B_{1}$ of the Cornell System (NFC); $k_{1}=$ specific rate $\left(h^{-1}\right)$ of gas production by the degradation of the fraction $A+B_{1}(N F C) ; V f_{2}$ : volume $(\mathrm{mL})$ of gas produced by the degradation of the fraction $B_{2}$ of fibre carbohydrates (CF); $k_{2}$ : specific rate $\left(h^{-1}\right)$ of production of gases by the degradation of the fraction $B_{2}$ $(\mathrm{FC}) ; \lambda$ : latency (h); SEM: standard error of mean

Means followed by the same letter do not differ $(P>0.05)$ by Tukey test

The high content of estimated TDN for custard apple and soursop seed cakes is explained by the higher content of EE in these cakes. Moreover, the lower lignin concentration increases the TDN and DE estimates owing to the lower presence of low digestible and non-digestible fibre.

As for the fractionation of nitrogen compounds (Table 2), the highest amounts of fraction A, which were quantified in the custard apple seed cake, indicate the possibility of using this by-product as a source of $\mathrm{N}$ that is readily available for use by rumen microorganisms. The protein fraction A in CNCPS, which was previously classified as non-protein nitrogen, was reclassified as ammonia for ease and availability of analysis and to provide a better prediction of the contribution of metabolizable protein of free amino acids and small peptides. According to Brandstetter et al. (2019), fraction A is essential for a good rumen function, since the structural carbohydrate rumen fermentation microorganisms use ammonia as a nitrogen source.

By relating fraction $A$ of nitrogen compounds to carbohydrate availability in fraction A+B1 (Table 2), which shows rapid ruminal degradation, there is a synchrony in nitrogen and carbohydrate degradation rates in the rumen when using this food in diets for ruminants. Thus, when a food has a high protein content and much of this protein is in the rapidly degrading fractions, it is necessary to provide a carbohydrate source with a high rate of ruminal degradation for rumen microbial protein synthesis to be efficient (Seo et al., 2013). 
The higher concentrations of total carbohydrates in the soursop and passion fruit seed cakes reflect the high contents of the fibre fraction. Fraction $\mathrm{C}$ of carbohydrates occurred in greater proportion in relation to fractions $A+B 1$ and $B 2$ for all the cakes. The largest participation of this fraction was found in passion fruit seed cake. This is a consequence of the high lignin content of the material, which decreases its digestion (Olivo et al., 2017). According to Van Soest et al. (1991), carbohydrate fraction C has an effect on rumen repletion, leading to lower energy availability because of lower potential intake per unit of time.

The custard apple seed cake presented the highest proportions of in vitro digestible compounds, which could be explained by the higher presence of estimated TDN and lower presence of lignin (Table 1), associated with the amount of protein available for more efficient fermentation. Custard apple seed cake also presented a higher concentration of fraction B3. According to Licitra et al. (1996), this protein fraction is associated with the cell wall with slow ruminal degradation rate and therefore presents a high escape.

The passion fruit seed cake presented the lowest degradability parameters (Table 3) for a (rapid degradation fraction), $b$ (insoluble, but degraded by microorganisms as a function of incubation time), and $c$ (fraction $b$ degradation rate according to incubation time). Potential degradation was considered low, since this type of analysis estimates the degradability of all compounds that can be degraded during the total incubation time (Mizubuti et al., 2011). In vitro dry matter degradability was considered low, since less than $30 \%$ of the dry matter was used by rumen microorganisms (Table 3 ).

The low degradation rate and IVDMD of passion fruit seed cake are explained by the higher amount of non-digestible carbohydrates (part C), which account for more than $80 \%$ total carbohydrates (Table 2). This carbohydrate fraction $\mathrm{C}$ is composed almost entirely of compounds such as lignin and lignocellulose complexes, which are not degraded by ruminal microorganisms.

The custard apple seed cake presented potential degradability of $574.0 \mathrm{~g} / \mathrm{kg} \mathrm{DM}$, which is considered good, since more than $50 \%$ nutrients in the cake are capable of degradation within 48 hours. This higher potential degradability could be because the higher concentration of fraction $A+B 1$ associated with the amount of protein available provides a more efficient fermentation if considered the same fraction of the other cakes.

In in vitro gas production, the total fermentation produced a larger final volume of gases for the custard apple seed cake, which demonstrates greater nutrient availability for the rumen microorganisms. The lower volume of gases produced by the fermentation of passion fruit seed cake may be because $80 \%$ carbohydrates are present in fraction $\mathrm{C}$, which is not digestible. The observed total gas volume $\left(\mathrm{V}_{\mathrm{t} 1}\right)$ was close to that estimated by the bicompartmental model $\left(\mathrm{V}_{\mathrm{t} 2}\right)$, confirming the fit of the model.

The larger total volume of gases produced by the fibre carbohydrates of custard apple seed cake may be explained by the lower lignin content in its composition, because this cake has more than $20 \% \mathrm{CP}$. According to Seo et al. (2013), for proper rumen fermentation there is a need for synchronization between the amount of carbohydrates and nitrogen compounds. Based on this, Lazzarini et al. (2009) stated that to optimize the non-digestible fibre fraction, microorganisms require about $11 \% \mathrm{CP}$ to properly use the fibre constituents of a given food.

Since these gases are the result of food degradation and the maximum potential of these parameters are aspects for food quality assessment, the custard apple seed cake presented better fermentation qualities, since its maximum potential and gas production rates were higher than in the other cakes.

\section{Conclusion}

Fruit seed cakes can be included in the ruminant diet and represent dietary alternatives that may reduce costs with animals raised in semiarid areas during periods of shortage. However, the inclusion of these ingredients must be balanced by other ingredients that meet the nutritional requirements according to the animal category.

\section{Acknowledgements}

To the Federal Rural University of Pernambuco, the Pos Graduate Program in Animal Science and Pastures, funded by Banco do Nordeste do Brasil - BNB and Coordenação de Aperfeiçoamento de Pessoal de Nível Superior CAPES and the Experimental Biofuel Plant of CETENE in Caetés, PE.

\section{Authors' Contributions}

CSP, ALT, GCG, FSC, DBN, LPO and IEL participated in designing the study, laboratory analysis, and writing the manuscript. ALRM, ALT, RMLV, APA were involved in drafting and revising the manuscript for important intellectual content. CSP, ALT, GCG, FSC and DBN did data analysis and interpretation and were involved in the preparation and revision of the manuscript. CSP, ALT, DBN, LPO and IEL contributed to the acquisition, analysis and interpretation of data.

\section{Conflict of Interest Declaration}

No potential conflict of interest was reported by the authors. 


\section{References}

AFRC, 1993. Agricultural and Food Research Council. Energy and protein requirements of ruminants. CAB International, Wallingford. $159 \mathrm{pp}$.

Almeida, J.C.S., Figueiredo, D.M., Azevedo, K.K., Paixão, M.L., Ribeiro, E.G. \& Dallago, G.M., 2019. Intake, digestibility, microbial protein production, and nitrogen balance of lambs fed with sorghum silage partially replaced with dehydrated fruit by-products. Trop. Anim. Health Prod. 5, 619-627. https://doi.org/10.1007/s11250-018-1734-0

AOAC (Association of Official Analytical Chemists), 2016. Official methods of analysis. 20th ed. Edited by G.W. Latimer Jr. Association of Official Analytical Chemists, Washington, DC. 3100 pp.

Assis, D.Y.C., Carvalho, G.G.P., Santos, E.M., Oliveira, F.A., Araújo, M.L.G.M.L., Pina, D.S., Santos, S.A. \& Rufino, L.M.A., 2019. Cottonseed cake as a substitute of soybean meal for goat kids. Italian J. Anim. Sci. 18,124-133. https://doi.org/10.1080/1828051X.2018.1490633

Braga, A.P., Amâncio, A.V.A.F., Gonçalves, J.S., Assis, L.C.S.L.C., Souza, C.M.S., Maia, I.S.A.S. \& Gerra, D.G.F., 2016. Ruminal degradability of agro-industrial fruit residues. Semina: Ci. Agr. 37, $279-292$. http://dx.doi.org/10.5433/1679-0359.2016v37n1p279

Brandstetter, E.V., Costa, K.A.P., Santos, D.C., Souza, W.F., Silva, V.C. \& Dias, M.B.C., 2019. Protein and carbohydrate fractionation of Jiggs Bermudagrass in different seasons and under intermittent grazing by Holstein cows. Acta Scient. Anim. Sci. 41, e43363. https://dx.doi.org/10.4025/actascianimsci.v41i1.43363

Costa, D.A., Ferreira, G.D.G., Araújo, C.V., Colodo, J.C.N., Moreira, G.R. \& Figueiredo, M.R.P., 2010. Intake and digestibility of diets with levels of palm kernel cake in sheep. Rev. Bras. Saúde Prod. Anim. 11, 783-792. http://www.rbspa.ufba.br/index.php/rbspa/article/viewFile/1779/1001

Goes, R.H.T.B., Silva, L.H.X., Diaz, T.G., Branco, A.F., Teodoro, A.L. \& Ferreira, G.R., 2019. Sunflower cake in diets for beef cattle: digestibility, kinetics and in vitro ruminal fermentation parameters. Acta Scient. Anim. Sci. 41, e39492. http://dx.doi.org/10.4025/actascianimsci.v41i1.39492

Holden, L.A., 1999. Comparison of methods of in vitro dry matter digestibility for ten feeds. J. Dairy Sci. 82, 1791-1794. http://dx.doi.org/10.3168/jds.S0022-0302(99)75409-3

Keles, G., Yildiz-Akgul, F. \& Kocaman, V., 2017. Performance and milk composition of dairy goats as affected by the dietary level of stoned olive cake silages. Asian-Austral. J. Anim. Sci. 30, 363-369. https://doi.org/10.5713/ajas.16.0482

Lazzarini, I., Detmann, E., Sampaio, C.B., Paulino, M.F., Valadares Filho, S.C., Souza, M.A. \& Oliveira, F.A., 2009. Transit and degradation dynamics of neutral detergent fiber in cattle fed low-quality tropical forage and nitrogenous compounds. Arq. Bras. Med. Vet. Zootec. 61, 635-647. http://dx.doi.org/10.1590/S010209352009000300017

Licitra, G., Hernandez, T.M. \& Van Soest, P.J., 1996. Standardization of procedures for nitrogen fractionation of ruminant feed. Anim. Feed Sci. Techn. 57, 347-358. https://doi.org/10.1016/0377-8401(95)00837-3.

Lima, A.G.V.O., Silva, T.M., Bezerra, L.R., Pereira, E.S., Barbosa, A.M., Ribeiro, R.D.X., Rocha, T.C., Trajano, J.S., Oliveira, R.L., 2018. Intake, digestibility, nitrogen balance, performance and carcass traits of Santa Ines lamb fed with sunflower cake from biodiesel production, Small Rum. Res. 168, 19-24. https://doi.org/10.1016/j.smallrumres.2018.09.003

Luz, J.B., Gomes, D.I., Santos Neta, E.R., Mezzomo, R., Oliveira, L.R.S., Silva, R.C., Reis, G.C. \& Alves, K.S., 2019. Performance and digestibility of confined lambs fed with Babassu cake (Orbignya speciosa) as a substitute for elephant grass silage. Arq. Bras. Med. Vet. Zootec. 71, 977-982. https://dx.doi.org/10.1590/1678-4162-10512

Maneerat, W., Prasanpanich, S., Tumwasorn, S., Laudadio, V. \& Tufarelli, V., 2015. Evaluating agro-industrial byproducts as dietary roughage source on growth performance of fattening steers. Saudi J. Biol. Sci. 22, 580-584. http://dx.doi.org/10.1016/j.sjbs.2015.01.015

Mertens, D.R., 2002. Gravimetric determination of amylase-treated neutral detergent fiber in feeds with refluxing in beaker or crucibles: Collaborative study. J. AOAC Int. 85, 1217-1240. https://www.ncbi.nlm.nih.gov/pubmed/12477183

Mizubuti, I.Y., Ribeiro, E.L.A., Pereira, E.S., Pinto, A.P., Franco, A.L.C., Syperreck, M.A., Dórea, J.R.R., Cunha, G.E., Capelari, M.G.M. \& Muniz, E.B., 2011. In vitro rumen fermentation kinetics of some co-products generated in the biodiesel production chain by gas production technique. Semina: Ciências Agrárias, Londrina, 32(supplement 1), 2021-2028. (In Portuguese) https://dx.doi.org/10.5433/1679-0359.2011v32Suplp2021

Nagalakshmi, D. \& Dhanalakshmi, K., 2015. Effect of feeding castor seed cake-based diets on growth, nutrient utilization, immune response and carcass traits in lambs. Asian J. Anim. Sci. 9, 293-305. https://dx.doi.org/10.3923/ajas.2015.293.305

NRC (National Research Council), 2001. Nutrient requirements of dairy cattle. 7th ed. The National Academy Press, Washington, DC. 381 pp.

Olivo, P.M., Santos, G.T., Ítavo, L.C.V., Silva Junior, R.C., Leal, E.S. \& Prado, R.M., 2017. Assessing the nutritional value of agroindustrial co-products and feed through chemical composition, in vitro digestibility, and gas production technique. Acta Scient. Anim. Sci. 39, 289-295, https://dx.doi.org/10.4025/actascianimsci.v39i3.34024

Ørskov, E.R. \& McDonald, I., 1979. The estimation of protein degradability in the rumen from incubation measurements weighted according to rate of passage. J. Agri. Sci. 92, 499-503. https://doi.org/10.1017/S0021859600063048

Schofield, P., Pitt, R. E. \& Pell, A.N., 1994. Kinetics of fiber digestion from in vitro gas production. J. Anim. Sci. 72, 298091. https://doi.org/10.2527/1994.72112980x 
Seo, J.K., Kim, M.H., Yang, J.Y., Kim, H.J., Lee, C.H., Kim, K.H. \& Ha, J.K., 2013. Effects of synchronicity of carbohydrate and protein degradation on rumen fermentation characteristics and microbial protein synthesis. Asian-Austral. J. Anim. Sci. 26, 358-365. http://dx.doi.org/10.5713/ajas.2012.12507

Silva, D.J. \& Queiroz, A.C., 2002. Análise de alimentos: métodos químicos e biológicos. 2. ed. Viçosa, MG: UFV/Imprensa Universitária, 235pp.

Sniffen, C.J., O'Connor, J.D. \& Van Soest, P.J., 1992. A net carbohydrate and protein system for evaluating cattle diets: II. Carbohydrate and protein availability. J. Anim. Sci. 70, 3562-3577. https://www.ncbi.nlm.nih.gov/pubmed/1459919

Terrill, T.H., Rowan, A.M., Douglas, G.B. \& Barry, T.N., 1992. Determination of extractable and bound condensed tannin concentrations in forage plants, protein concentrate meals and cereal grains. J. Sci. Food Agr. 58, $321-329$. https://doi.org/10.1002/jsfa.2740580306

Theodorou, M.K., Williams, B.A., Dhanoa, M.S., McAllan, A.B. \& France, J., 1994. A simple gas production method using a pressure transducer to determine the fermentation kinetics of ruminant feeds. Anim. Feed Sci. Techn. 48, 18597. https://doi.org/10.1016/0377-8401(94)90171-6

Tilley, J.M.A. \& Terry, R.A., 1963. A two-stage technique for the in vitro digestion of forage crops. Grass Forage Sci. 18, 104-111. https://onlinelibrary.wiley.com/doi/abs/10.1111/j.1365-2494.1963.tb00335.x

Tinsley, T.L., Chumbley, S., Mathis, C., Machen, R. \& Turner, B.L., 2019. Managing cow herd dynamics in environments of limited forage productivity and livestock marketing channels: An application to semi-arid Pacific island beef production using system dynamics. Agric. Sys. 173, 78-93.DOI: 10.1016/j.agsy.2019.02.014

Torres-León, C., Ramírez-Guzman, N., Londoño-Hernandez, L., Martinez-Medina, G.A., Díaz-Herrera, R., NavarroMacias, V., Alvarez-Pérez, O.B., Villarreal-Vázquez, B.P.M., Ascacio-Valdes, J. \& Aguilar. C.N., 2018. Food waste and by-products: An opportunity to minimize malnutrition and hunger in developing countries. Front. Sust. Food Sys. 2, 1-17. https://doi.org/10.3389/fsufs.2018.00052

Valente, T.N.P., Detmann, E., Queiroz, A.C., Valadares Filho, S.C., Gomes, D.I. \& Figueiras, J.F., 2011. Evaluation of ruminal degradation profiles of forages using bags made from different textiles. Rev. Bras. Zootec. 40, 2565-2573. https://dx.doi.org/10.1590/S1516-35982011001100039

Van Soest, P.J., Robertson, J.B. \& Lewis, B.A., 1991. Methods for dietary fiber, neutral detergent fiber, and non-starch polysaccharides in relation to animal nutrition. J. Dairy Sci. 74, 3583-3597. DOI: 10.3168/jds.S00220302(91)78551-2 